\title{
Electrochemical Detection of Arsenite with Silver Electrodes in Inorganic Electrolyte and Natural System Mixtures
}

\author{
María del C. Aguirre, ${ }^{a, b}$ Bernabe L. Rivas, ${ }^{*, a}$ Luiz Basáez $^{a}$ and Carlos Peña-Farfal ${ }^{c}$ \\ ${ }^{a}$ Polymer Department, Faculty of Chemistry, University of Concepción, Casilla 160-C, Concepción, Chile \\ ${ }^{b}$ Materials Science Group, Faculty of Mathematics, Astronomy and Physics, \\ National University of Córdoba, Argentina \\ ${ }^{c}$ Department of Instrumental Analysis, Faculty of Chemistry and Pharmacy, \\ University of Concepción, 4070043-Concepcion, Chile
}

\begin{abstract}
A detecção eletroquímica de arsenito com eletrodos de fio de prata (SWE) ou de disco de prata (SDE) foi realizada em soluções aquosas inorgânicas, as quais são similares àquelas encontradas em condições naturais. Voltametria cíclica (CV), voltametria de varredura linear (LSV) e voltametria de redissolução anódica (ASV) foram aplicadas. Os fatores investigados foram $\mathrm{pH}$, natureza e concentração do eletrodo de suporte e tempo e voltagem de deposição para ASV. As mudanças de corrente e potencial de pico anódicos de As(III) em soluções padrão (por exemplo, $0,1 \mathrm{~mol} \mathrm{~L}^{-1} \mathrm{Na}_{2} \mathrm{SO}_{4}, \mathrm{NaNO}_{3}, \mathrm{HNO}_{3}$ and $\mathrm{H}_{2} \mathrm{SO}_{4}$ ) foram avaliadas. Os meios neutro e básico de sais inorgânicos intensificaram a sensibilidade do eletrodo de prata mais que o meio ácido. Então, foi possível trabalhar em meio alcalino com sensibilidade aumentada para As(III) (limite de detecção de $90 \mathrm{ng} \mathrm{L}^{-1}$ ). A resposta analítica melhorada fez este sistema comparável a um eletrodo de nanoarranjo. Como o intervalo de uso destes eletrodos era largo, SWE (área de 6,47 $\mathrm{mm}^{2}$ ) foi aplicado para monitorar a água de torneira usando $0,1 \mathrm{~mol} \mathrm{~L}^{-1} \mathrm{Na}_{2} \mathrm{SO}_{4}$ como eletrodo de suporte para detectar quantidades acima de $0,5 \mu \mathrm{g} \mathrm{L} \mathrm{L}^{-1} \mathrm{As}(\mathrm{III})$.
\end{abstract}

The electrochemical detection of arsenite with silver wire (SWE) or silver disc (SDE) electrodes was carried out in inorganic aqueous solutions, which are similar to those found under natural conditions. Cyclic voltammetry (CV), linear sweep voltammetry (LSV) and anodic stripping voltammetry (ASV) were applied. The investigated factors were $\mathrm{pH}$, nature and concentration of supporting electrolyte and deposition time and voltage for ASV. The changes in the As(III) anodic peak current and potential in standard solutions (e.g., $0.1 \mathrm{~mol} \mathrm{~L}-1 \mathrm{Na}_{2} \mathrm{SO}_{4}, \mathrm{NaNO}_{3}, \mathrm{HNO}_{3}$ and $\mathrm{H}_{2} \mathrm{SO}_{4}$ ) were evaluated. The neutral and basic media of inorganic salts were found to enhance the silver electrode sensitivity more than the acidic media. Thus, it was possible to work in alkaline medium with increased sensitivity for As(III) (limit of detection of $90 \mathrm{ng} \mathrm{L}^{-1}$ ). The improved analytical response made this system comparable to a nanoarray electrode. As the range of use of these electrodes was wide, SWE (area of $6.47 \mathrm{~mm}^{2}$ ) was applied to monitor tap water using $0.1 \mathrm{~mol} \mathrm{~L}^{-1}$ $\mathrm{Na}_{2} \mathrm{SO}_{4}$ as supporting electrolyte to successfully detect quantities above $0.5 \mu \mathrm{g} \mathrm{L}{ }^{-1} \mathrm{As}(\mathrm{III})$.

Keywords: arsenite electrooxidation, silver electrodes, electrochemical detection, tap water

\section{Introduction}

Arsenic is a metalloid that naturally exists in the oxidation states $3+, 5+, 0$ and 3-. Its toxicity depends on its complex form, being the organic arsenic less toxic than the inorganic one. ${ }^{1}$ Specifically, the inorganic As(III) state is 10 times more mobile and toxic than $\mathrm{As}(\mathrm{V})$. The permitted level in

*e-mail: brivas@udec.cl water is $10 \mu \mathrm{g} \mathrm{L}{ }^{-1}$ according to World Health Organization (WHO). The mobility of arsenic compounds and their water rejection ability depend on the cations and anions that coexist in the natural media. The As(III) determination at low concentrations in aqueous solutions has been widely performed using electrochemical methods. ${ }^{2-6}$

As(III) traces in natural waters and biological materials were previously determined using a gold disc electrode. ${ }^{7}$ However, the sodium chloride concentration must be 
limited when used as supporting electrolyte since the excess causes the formation of two oxidation peaks. Additionally, copper and antimony have been found to produce interference when a gold-film electrode was used to determine As(III) by anodic stripping voltammetry (ASV). ${ }^{8}$ These elements, when in seawater, do not significantly interfere with arsenic determination. ${ }^{7,8}$

The use of platinum nanoparticle modified glassy carbon as electrodes for the analytical determination of the As(III) oxidation peak does not suffer from $\mathrm{Cu}$ (II) interference, in contrast to other metal surfaces (especially gold) that are typically used to detect arsenic. ${ }^{9}$ Contrary to previous studies, ${ }^{10}$ it was found that As(III) could be determined by ASV using a gold microwire electrode at any $\mathrm{pH}$ (including the neutral $\mathrm{pH}$, typical for natural water). Gold, platinum and silver ${ }^{11}$ were also investigated as electrode substrates for arsenic detection via anodic stripping voltammetry. The combination with ultrasound increased the level of arsenic detection $\left(10^{-8} \mathrm{~mol} \mathrm{~L}^{-1}\right)$. The arsenic determination was optimized using a silver macroelectrode, which is similar to the one in this work, but in acidic media. The authors also studied the copper interference in the determination because it formed intermetallic compounds with arsenic.

Additionally, silver electrodes are nontoxic, the standard potential of the system is high $(+0.7991 \mathrm{~V})^{12,13}$ and the analytical range of these electrodes is wide (for example, $10^{-1}$ to $10^{-8} \mathrm{~mol} \mathrm{~L}^{-1}$ for halide). ${ }^{12}$ Silver electrodes allow not only anions but also a number of cations and a significant number of organic substances (including high-molecular substances and surfactants) to be quantitatively determined.

The present study targets the electrochemical detection of arsenite species by silver wire electrode (SWE) or silver disc electrode (SDE) with cyclic (CV), linear sweep (LSV) and anodic stripping (ASV) voltammetric methods, studying the produced effect by the nature and concentration of the supporting electrolyte and the $\mathrm{pH}$ range. ASV and CV were applied to extend the lower limit of detection. The SWE response was studied for low and high arsenite concentrations in drinking water media. The main advantages of the developed method were simplicity, low cost, no required derivatization, simple instrumentation and the possibility of constructing miniature devices using small electrodes (e.g., silver screen printed electrodes for small sample volumes).

\section{Experimental}

\section{Reagents}

High purity $0.1 \mathrm{~mol} \mathrm{~L}^{-1}$ sulfuric acid and hydrochloric acid were prepared from suprapure reagents (Merck). The
$0.1 \mathrm{~mol} \mathrm{~L}^{-1} \mathrm{NaNO}_{3}, \mathrm{Na}_{2} \mathrm{SO}_{4}, \mathrm{NaHCO}_{3}, \mathrm{NaCl}, \mathrm{CaCl}_{2}$ and $\mathrm{Mg}_{2} \mathrm{SO}_{4}$ solutions were prepared from solid salts (Merck, analytical grade). A standard solution of $1.5 \mathrm{~g} \mathrm{~L}^{-1} \mathrm{As}$ (III) (0.02 $\left.\mathrm{mol} \mathrm{L}^{-1}\right)$ was prepared by dissolving the adequate quantity of $\mathrm{NaAsO}_{2}$ (Merck) in deionized water (final $\mathrm{pH} 9.0$ ) or in a $0.1 \mathrm{~mol} \mathrm{~L}^{-1} \mathrm{NaOH}$ solution (Aldrich). All solutions were prepared using milli-Q water from a water purification system (Millipore, MA, USA).

\section{Electrodes, electrochemical cells and instrumentation}

All experiments were carried out with a CHI 604C electrochemical analyzer. Standard three-electrode cells were used for analytical experiments. An $\mathrm{Ag} / \mathrm{AgCl}$ reference electrode in $3 \mathrm{~mol} \mathrm{~L}^{-1} \mathrm{KCl}$ (CHI 111) and a platinum wire as counter electrode were used. The silver wire electrode (area of $6.47 \mathrm{~mm}^{2}$ ) and silver disc electrode (area of $10.21 \mathrm{~mm}^{2}$ ) were polished with $1 \mu \mathrm{m}$ diamond paste and used for analytical determinations. Cyclic voltammetry was applied in the potential range of $0.1-0.5 \mathrm{~V}$ using scan rates of $100,50,20$ or $10 \mathrm{mV} \mathrm{s}^{-1}$.

\section{As(III) determination}

In all cases, $10 \mathrm{~mL}$ of aqueous solution containing the electrolyte support of interest or drinking water were used. Standard solutions of $0.1 \mathrm{~mol} \mathrm{~L}^{-1} \mathrm{H}_{2} \mathrm{SO}_{4}$ and $0.1 \mathrm{~mol} \mathrm{~L}^{-1}$ $\mathrm{Na}_{2} \mathrm{SO}_{4}$ were used as electrolyte support, with a highly concentrated solution of $20 \mathrm{mmol} \mathrm{L}^{-1} \mathrm{As}(\mathrm{III})$. The diluted solutions of these standards were assayed under the same conditions. Drinking or tap water containing $0.1 \mathrm{~mol} \mathrm{~L}^{-1}$ $\mathrm{Na}_{2} \mathrm{SO}_{4}$ solution was prepared and contaminated with known quantities of As(III). The calibration curve at the lowest and highest concentrations was plotted. Linear sweep anodic stripping voltammetry was applied with SWE $\left(6.47 \mathrm{~mm}^{2}\right)$ in a $15 \mathrm{~mL}$ standard solution of $0.003 \mathrm{~mol} \mathrm{~L}^{-1}$ $\mathrm{Na}_{2} \mathrm{SO}_{4}$ and $0.01 \mathrm{mmol} \mathrm{L}^{-1} \mathrm{As}(\mathrm{III})$. Additionally, diluted solutions of $\mathrm{NaHCO}_{3}, \mathrm{NaCl}, \mathrm{Na}_{2} \mathrm{SO}_{4}, \mathrm{MgSO}_{4}$ and $\mathrm{CaCl}_{2}$ were prepared and assayed alone and mixed with $\mathrm{As}(\mathrm{III})$.

\section{Results and Discussion}

\section{Arsenite oxidation in different supporting electrolytes}

The supporting electrolyte effect on the As(III) anodic response on the silver wire and disc electrodes was studied by CV. Among the examined electrolytes (i.e., $0.1 \mathrm{~mol} \mathrm{~L}^{-1}$ $\mathrm{Na}_{2} \mathrm{SO}_{4}, \mathrm{H}_{2} \mathrm{SO}_{4}, \mathrm{NaNO}_{3}$ and $\mathrm{HNO}_{3}$ ), $\mathrm{Na}_{2} \mathrm{SO}_{4}$ and $\mathrm{NaNO}_{3}$ provided the highest well-defined anodic peak currents.

Because any anion can form a complex with As(III), what can modify its electrochemical properties, only 
$0.1 \mathrm{~mol} \mathrm{~L}^{-1} \mathrm{NaOH}$ was used to adjust the $\mathrm{pH}$ value. Electrochemical detection of As(III) by silver wire and silver disc electrodes using cyclic voltammetry with the inorganic solutions that was above mentioned was carried out in the $\mathrm{pH}$ ranges of 7.0-9.0 and 7.0-13.0. In all cases, the characterized anodic response by As(III) was near $0.3 \mathrm{~V}$.

\section{$0.1 \mathrm{~mol} \mathrm{~L}^{-1} \mathrm{HNO}_{3}$ and $\mathrm{NaNO}_{3}$}

The cyclic voltammetric curves of As(III) for SDE $(\varnothing=5 \mathrm{~mm})$ at $100 \mathrm{mV} \mathrm{s}^{-1}$ for the range of $-0.5-0.5 \mathrm{~V}$ in $0.1 \mathrm{~mol} \mathrm{~L}^{-1} \mathrm{HNO}_{3}$ are shown in Figure 1. A typical assay in blank media (without As(III)) is curve a, while curve b shows a well-defined $\mathrm{As}(\mathrm{III})$ reduction wave at $-0.3 \mathrm{~V}$ and an oxidation wave at $0.24 \mathrm{~V}$, as previously reported for the conversion of $\mathrm{As}(0)$ to $\mathrm{As}(\mathrm{III}) .{ }^{11}$ The reduction process at $0.4 \mathrm{~V}$ was associated with the reduction of the silver in the electrode (curve a) in absence of As(III).

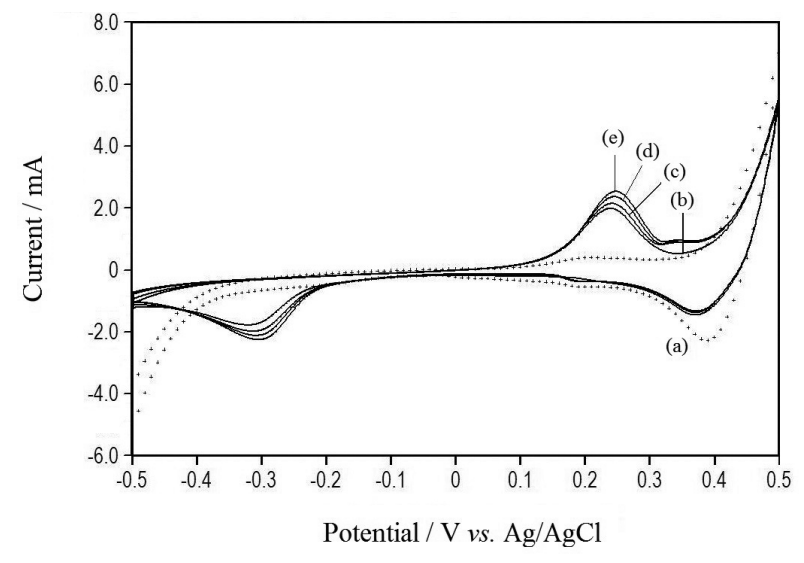

Figure 1. $\mathrm{CV}$ curves of $\mathrm{SDE}\left(19.3 \mathrm{~mm}^{2}\right)$ in $0.1 \mathrm{~mol} \mathrm{~L}^{-1} \mathrm{HNO}_{3}$ at scan rate of $100 \mathrm{mV} \mathrm{s}^{-1}$ : (a) in the absence of arsenic, (b) 1.7, (c) 2.6, (d) 3.4 and (e) $4.25 \mathrm{mmol} \mathrm{L}^{-1} \mathrm{As}(\mathrm{III})$.

SWE $\left(6.47 \mathrm{~mm}^{2}\right)$ at $50 \mathrm{mV} \mathrm{s}^{-1}$ in unbuffered $0.1 \mathrm{~mol} \mathrm{~L}^{-1}$ $\mathrm{NaNO}_{3}$ solution ( $\mathrm{pH}$ ca. 7.0-9.0) showed just one irreversible anodic peak at $0.35 \mathrm{~V}$ (Figure 2). A typical assay in blank media was curve a, which did not show anodic peaks in the range of $0.12-0.5 \mathrm{~V}$ for silver oxidation. Although the present authors were interested in analyzing the role of silver oxides (e.g., $\mathrm{Ag}_{2} \mathrm{O}$ ) on the wave oxidation of arsenic, it was not clear that any effect on the As(III) signal (seen as a shoulder in the silver oxidation wave) existed. The increase in the anodic peak currents was proportional to arsenic concentration, and the $\mathrm{pH}$ of the solution was increased from 7.0 to 9.0. The net currents $\left(I_{c}\right)$ shown in the inset of Figure 2 were calculated on the basis of the current peak, subtracting the background of the $0.1 \mathrm{~mol} \mathrm{~L}^{-1} \mathrm{NaNO}_{3}$ solution without As(III) (curve a). The linear least square calibration curve over the range of 0.098-1.000 $\mathrm{mmol} \mathrm{L}^{-1}$
(24 points) was $\mathrm{I}(\mu \mathrm{A})=29.7 \mathrm{C}_{\mathrm{As}(\mathrm{III})}\left(\mathrm{mmol} \mathrm{L}^{-1}\right)$ with a correlation coefficient $\left(\mathrm{r}^{2}\right)$ of 0.998 , indicating that the regression line fit very well the experimental data. Several experiments in the same conditions resulted in linearity ranges of $0.045-1.000 \mathrm{mmol} \mathrm{L}^{-1}$ with values of anodic current density in the order of 3.86-4.60 $\mu \mathrm{A} \mathrm{mm}^{-2}$ up to $1 \mathrm{mmol} \mathrm{L}^{-1}$ $\mathrm{As}(\mathrm{III})$. An increase in the SWE area $\left(10.21 \mathrm{~mm}^{2}\right)$ increased the current density to $5.87-8.12 \mu \mathrm{A} \mathrm{mm}^{-2}$ for a similar linear range of As(III) concentration.

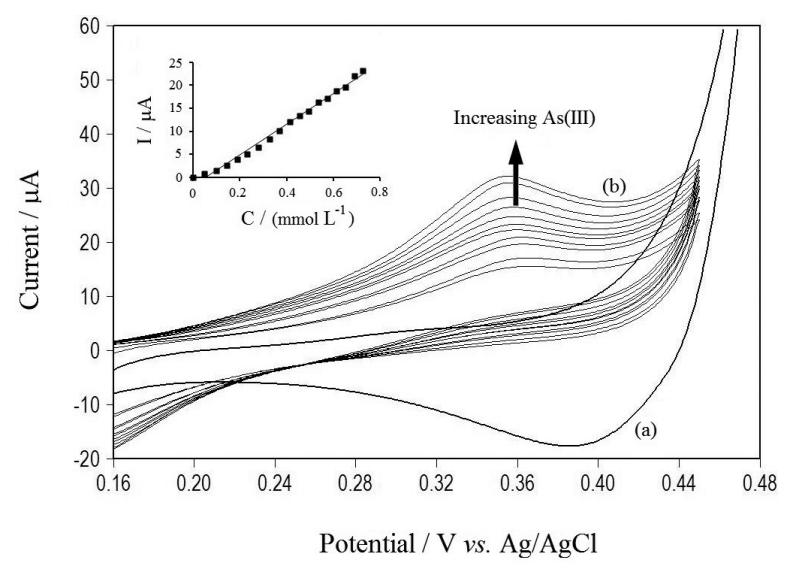

Figure 2. $\mathrm{CV}$ curves of $\mathrm{SWE}\left(6.47 \mathrm{~mm}^{2}\right)$ in $0.1 \mathrm{~mol} \mathrm{~L}^{-1} \mathrm{NaNO}_{3}$ at scan rate of $50 \mathrm{mV} \mathrm{s}^{-1}$ : (a) in the absence of arsenic and (b) $1 \mathrm{mmol} \mathrm{L}^{-1} \mathrm{As}(\mathrm{III})$.

\section{$0.1 \mathrm{~mol} \mathrm{~L}^{-1} \mathrm{Na}_{2} \mathrm{SO}_{4}$ and $\mathrm{H}_{2} \mathrm{SO}_{4}$}

The electrochemical behavior of $\mathrm{As}(\mathrm{III})$ in $\mathrm{Na}_{2} \mathrm{SO}_{4}$ solutions was investigated with $\operatorname{SWE}\left(6.47 \mathrm{~mm}^{2}\right)$ by $\mathrm{CV}$, LSV and ASV. CV with a scan rate of $50 \mathrm{mV} \mathrm{s}^{-1}$ in $0.1 \mathrm{~mol} \mathrm{~L}^{-1}$ $\mathrm{Na}_{2} \mathrm{SO}_{4}$ and up to $2 \mathrm{mmol} \mathrm{L}^{-1} \mathrm{As}(\mathrm{III})$ showed a similar profile to the one in $0.1 \mathrm{~mol} \mathrm{~L}^{-1} \mathrm{NaNO}_{3}$ but with an increase in the anodic peak current values (profile b) at $0.35 \mathrm{~V}$. The calibration curve had a slope of $23.09 \mu \mathrm{A} \mathrm{mmol}^{-1} \mathrm{~L}$ with a linear correlation factor of 0.988 . The calculated current density was $6.2 \mu \mathrm{A} \mathrm{mm}^{-2}$. In addition, the oxidation potential was independent of the As(III) concentration. The oxidation peak for As(III) occurred at a slightly less positive potential than for the $\mathrm{Ag}_{2} \mathrm{O}$ formation at $0.34-0.42 \mathrm{~V}^{13}$ In sodium salt electrolytes, it was suggested that some As(III) was adsorbed at the oxide-free Ag electrode surface. Meanwhile, most of the reaction occurred at the As(III) oxidation onset, and the oxide formation simultaneously occurred to produce a peak response at $0.35-0.36 \mathrm{~V}$.

The majority of studies ${ }^{14-16}$ reported the use of inorganic acid or salts as supporting electrolytes between the concentrations of 1.0 and $0.1 \mathrm{~mol} \mathrm{~L}^{-1}$. The dilution effect of the $\mathrm{Na}_{2} \mathrm{SO}_{4}$ electrolyte support on the current peak was also examined. Figure 3 presents the values of anodic current $v s$. the supporting electrolyte concentration, in which the current of As(III) at each point of the curve was observed to be the 
result of voltammograms from different applied assays for electrolyte concentrations of $0.001,0.002,0.05,0.01$ and $0.1 \mathrm{~mol} \mathrm{~L}^{-1}$. The reported net current was for $1 \mathrm{mmol}$

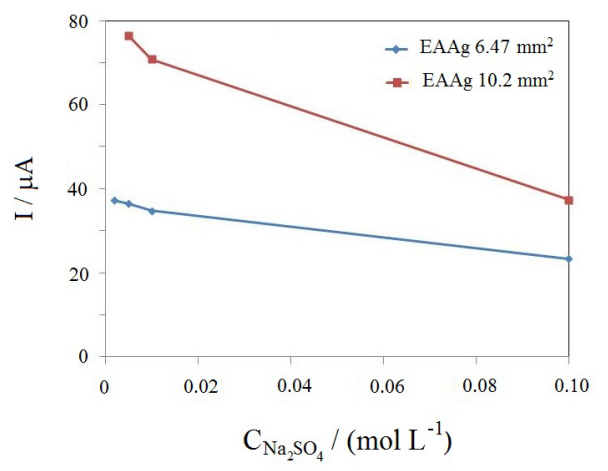

Figure 3. The net current calculated from $\mathrm{CV}$ for $1 \mathrm{mmol} \mathrm{L}^{-1} \mathrm{As}(\mathrm{III})$ vs. molar concentration of $\mathrm{Na}_{2} \mathrm{SO}_{4}$ supporting electrolyte with SWE $\left(6.47 \mathrm{~mm}^{2}\right)$ and $\mathrm{SWE}\left(10.21 \mathrm{~mm}^{2}\right)$, at scan rate of $50 \mathrm{mV} \mathrm{s}^{-1}$ and $\mathrm{pH} 7.0-9.0$.
$\mathrm{L}^{-1} \mathrm{As}(\mathrm{III})$ solutions and obtained from the slope of the calibration curve applying linear regression (see Table 1).

To further characterize dilution effects, an amount between 0.1 and $2.5 \mathrm{mmol} \mathrm{L}^{-1} \mathrm{As}(\mathrm{III})$ was added to each $\mathrm{Na}_{2} \mathrm{SO}_{4}$ solution and then, monitored by $\mathrm{CV}$. The results with SWE $\left(6.47\right.$ or $\left.10.21 \mathrm{~mm}^{2}\right)$ showed that the current slightly increased when the $\mathrm{Na}_{2} \mathrm{SO}_{4}$ concentration decreased. This effect was increasingly significant with increasing electrode area. The lowest concentration electrolyte did not change or only slightly enhanced the ionic conductivity of the solutions because the ions were too far apart to exert appreciable interionic forces. This poor interionic force reduced the interference on the electrode response and contributed to the good linearity for the lowest supporting electrolyte concentration.

In comparison to the sodium salts, acidic solutions resulted in slower electron transfer kinetics and less

Table 1. Calibration curves, I vs. $\mathrm{C}_{\mathrm{As} \text { (III) }}$ (in $\mu \mathrm{A}$ and $\mathrm{mmol} \mathrm{L}^{-1}$, respectively), obtained by $\mathrm{CV}$ at different supporting electrolyte concentrations (pH 7.0-9.0). $\mathrm{J}$ is the current density at $1 \mathrm{mmol} \mathrm{L}^{-1} \mathrm{As}(\mathrm{III})$

\begin{tabular}{|c|c|c|c|}
\hline Electrolyte & $\mathrm{E}_{\mathrm{ox}} / \mathrm{V}$ & $\begin{array}{l}\operatorname{SWE}\left(6.47 \mathrm{~mm}^{2}\right) \text { or } \\
\operatorname{SDE}^{\mathrm{a}}\left(7.00 \mathrm{~mm}^{2}\right)\end{array}$ & SWE $\left(10.21 \mathrm{~mm}^{2}\right)$ \\
\hline $0.100 \mathrm{~mol} \mathrm{~L}^{-1} \mathrm{Na}_{2} \mathrm{SO}_{4}$ & 0.35 & $\begin{array}{c}\mathrm{I}=23.09 \mathrm{C}_{\mathrm{As}(\mathrm{IIII}}, \mathrm{r}^{2}=0.988 \\
0.098-1.8 \mathrm{mmol} \mathrm{L}^{-1} \mathrm{As}(\mathrm{III}) \\
\mathrm{J}=3.57 \mu \mathrm{Amm}^{-2}\end{array}$ & $\begin{array}{c}\mathrm{I}=37.36 \mathrm{C}_{\mathrm{As}(\mathrm{III})}, \mathrm{r}^{2}=0.996 \\
0.061-1.22 \mathrm{mmol} \mathrm{L}^{-1} \mathrm{As}(\mathrm{III}) \\
\mathrm{J}=3.66 \mu \mathrm{A} \mathrm{mm}{ }^{-2}\end{array}$ \\
\hline $0.100 \mathrm{~mol} \mathrm{~L}^{-1} \mathrm{Na}_{2} \mathrm{SO}_{4}$ & 0.35 & $\begin{array}{c}\mathrm{I}^{\mathrm{a}}=32.20 \mathrm{C}_{\mathrm{As}(\mathrm{III})}, \mathrm{r}^{2}=0.99 \\
0.192-1.43 \mathrm{mmol} \mathrm{L}^{-1} \mathrm{As}(\mathrm{III}) \\
\mathrm{J}=4.60 \mu \mathrm{A} \mathrm{mm}{ }^{-2}\end{array}$ & - \\
\hline $0.010 \mathrm{~mol} \mathrm{~L}^{-1} \mathrm{Na}_{2} \mathrm{SO}_{4}$ & 0.3 & $\begin{array}{c}\mathrm{I}=34.7 \mathrm{C}_{\mathrm{As}(\mathrm{III})}, \mathrm{r}^{2}=0.990 \\
0.198-2.6 \mathrm{mmol} \mathrm{L}^{-1} \mathrm{As}(\mathrm{III}) \\
\mathrm{J}=5.36 \mu \mathrm{A} \mathrm{mm} \mathrm{mm}^{-2}\end{array}$ & $\begin{array}{c}\mathrm{I}=70.74 \mathrm{C}_{\mathrm{As}(\mathrm{IIII}}, \mathrm{r}^{2}=0.98 \\
0.198-2.6 \mathrm{mmol} \mathrm{L}^{-1} \mathrm{As}(\mathrm{III}) \\
\mathrm{J}=6.93 \mu \mathrm{A} \mathrm{mm}{ }^{-2}\end{array}$ \\
\hline $0.005 \mathrm{~mol} \mathrm{~L}^{-1} \mathrm{Na}_{2} \mathrm{SO}_{4}$ & 0.28 & $\begin{array}{c}\mathrm{I}=36.43 \mathrm{C}_{\mathrm{As}(\mathrm{III})}, \mathrm{r}^{2}=0.99 \\
0.198-2.6 \mathrm{mmol}^{-1} \mathrm{As}(\mathrm{III}) \\
\mathrm{J}=5.63 \mu \mathrm{A} \mathrm{mm} \mathrm{mm}^{-2}\end{array}$ & $\begin{array}{c}\mathrm{I}=76.28 \mathrm{C}_{\mathrm{As}(\mathrm{III} I}, \mathrm{r}^{2}=0.992 \\
0.198-2 \mathrm{mmol} \mathrm{L}^{-1} \mathrm{As}(\mathrm{III}) \\
\mathrm{J}=7.47 \mu \mathrm{A} \mathrm{mm}{ }^{-2}\end{array}$ \\
\hline $0.002 \mathrm{~mol} \mathrm{~L}^{-1} \mathrm{Na}_{2} \mathrm{SO}_{4}$ & 0.27 & $\begin{array}{c}\mathrm{I}=37.25 \mathrm{C}_{\mathrm{As}(\mathrm{III})}, \mathrm{r}^{2}=0.99 \\
0.198-1.8 \mathrm{mmol}^{-1} \mathrm{As}(\mathrm{III}) \\
\mathrm{J}=5.76 \mu \mathrm{Amm}^{-2}\end{array}$ & - \\
\hline $0.001 \mathrm{~mol} \mathrm{~L}^{-1} \mathrm{Na}_{2} \mathrm{SO}_{4}$ & 0.27 & $\begin{array}{c}\mathrm{I}=31.69 \mathrm{C}_{\mathrm{As}(\mathrm{IIII}}, \mathrm{r}^{2}=0.989 \\
0.198-1.8 \mathrm{mmol}^{-1} \mathrm{As}(\mathrm{III}) \\
\mathrm{J}=4.89 \mu \mathrm{Amm}^{-2}\end{array}$ & - \\
\hline $0.100 \mathrm{~mol} \mathrm{~L}^{-1} \mathrm{H}_{2} \mathrm{SO}_{4}$ & 0.24 & $\begin{array}{c}\mathrm{I}=7.526 \mathrm{C}_{\mathrm{As}(\mathrm{III}}, \mathrm{r}^{2}=0.991 \\
0.041-1 \mathrm{mmol} \mathrm{L}^{-1} \mathrm{As}(\mathrm{III}) \\
\mathrm{J}=1.16 \mu \mathrm{Amm}^{-2}\end{array}$ & $\begin{array}{c}\mathrm{I}=11.15 \mathrm{C}_{\mathrm{As}(\mathrm{III}}, \mathrm{r}^{2}=0.96 \\
0.041-1.5 \mathrm{mmol} \mathrm{L}^{-1} \mathrm{As}(\mathrm{III}) \\
\mathrm{J}=1.09 \mu \mathrm{A} \mathrm{mm} \mathrm{mm}^{-2}\end{array}$ \\
\hline $0.100 \mathrm{~mol} \mathrm{~L}^{-1} \mathrm{NaNO}_{3}$ & 0.35 & $\begin{array}{c}\mathrm{I}=30.7 \mathrm{C}_{\mathrm{As}(\mathrm{III} I}, \mathrm{r}^{2}=0.998 \\
0.098-1 \mathrm{mmol} \mathrm{L}^{-1} \mathrm{As}(\mathrm{III}) \\
\quad \mathrm{J}=4.74 \mu \mathrm{A} \mathrm{mm} \mathrm{mm}^{-2}\end{array}$ & $\begin{array}{c}\mathrm{I}=83.41 \mathrm{C}_{\mathrm{As}(\mathrm{III}}, \mathrm{r}^{2}=0.98 \\
0.012-0.55 \mathrm{mmol} \mathrm{L}^{-1} \mathrm{As}(\mathrm{III}) \\
\mathrm{J}=8.17 \mu \mathrm{A} \mathrm{mm}{ }^{-2}\end{array}$ \\
\hline $0.100 \mathrm{~mol} \mathrm{~L}^{-1} \mathrm{NaNO}_{3}$ & 0.35 & $\begin{array}{c}\mathrm{I}^{\mathrm{a}}=29.68 \mathrm{C}_{\mathrm{As}(\mathrm{IIII}}, \mathrm{r}^{2}=0.982 \\
0.049-0.8 \mathrm{mmol} \mathrm{L}^{-1} \mathrm{As}(\mathrm{III}) \\
\mathrm{J}=4.24 \mu \mathrm{A} \mathrm{mm}{ }^{-2}\end{array}$ & - \\
\hline $0.002 \mathrm{~mol} \mathrm{~L}^{-1} \mathrm{NaNO}_{3}$ & 0.35 & $\begin{array}{c}\mathrm{I}=36.6 \mathrm{C}_{\mathrm{As}(\mathrm{IIII}}, \mathrm{r}^{2}=0.991 \\
0.198-2.46 \mathrm{mmol} \mathrm{L}^{-1} \mathrm{As}(\mathrm{III}) \\
\mathrm{J}=5.66 \mu \mathrm{A} \mathrm{mm} \mathrm{mm}^{-2}\end{array}$ & - \\
\hline $0.100 \mathrm{~mol} \mathrm{~L}^{-1} \mathrm{HNO}_{3}$ & 0.24 & $\begin{array}{c}\mathrm{I}=7.4 \mathrm{C}_{\mathrm{As}(\mathrm{IIII}}, \mathrm{r}^{2}=0.98 \\
0.098-0.83 \mathrm{mmol} \mathrm{L}^{-1} \mathrm{As}(\mathrm{III}) \\
\mathrm{J}=1.14 \mu \mathrm{Amm}^{-2}\end{array}$ & $\begin{array}{c}\mathrm{I}=11.29 \mathrm{C}_{\mathrm{As}(\mathrm{III} I}, \mathrm{r}^{2}=0.993 \\
0.049-1 \mathrm{mmol} \mathrm{L}^{-1} \mathrm{As}(\mathrm{III}) \\
\mathrm{J}=1.106 \mu \mathrm{Amm}^{-2}\end{array}$ \\
\hline
\end{tabular}


current peak sensitivity. For example, the sensitivity for As(III) with SWE or SDE in $0.1 \mathrm{~mol} \mathrm{~L}^{-1} \mathrm{H}_{2} \mathrm{SO}_{4}$ was three times lower than that found for the corresponding sodium salts (oxidation potential of $0.29 \mathrm{~V}$ for $\mathrm{pH}$ 2.2-7.0). CVs for SWE $\left(10.21 \mathrm{~mm}^{2}\right)$ at $50 \mathrm{mV} \mathrm{s}^{-1}$ are presented. The calibration curve was $\mathrm{I}(\mu \mathrm{A})=11.15 \mathrm{C}_{\mathrm{As}(\mathrm{III})}\left(\mathrm{mmol} \mathrm{L}^{-1}\right)$ (0.45-1.50 $\left.\mathrm{mmol} \mathrm{L}^{-1} \mathrm{As}(\mathrm{III})\right)$ with a correlation coefficient of 0.960 . The analysis with SWE $\left(6.47 \mathrm{~mm}^{2}\right)$ indicated I $(\mu \mathrm{A})=7.526 \mathrm{C}_{\mathrm{As}(\mathrm{III})}\left(\mathrm{mmol} \mathrm{L}^{-1}\right)$ and $\mathrm{r}^{2}=0.991$. The obtained results with $0.1 \mathrm{~mol} \mathrm{~L}^{-1} \mathrm{HNO}_{3}$ were close to those ones with $0.1 \mathrm{~mol} \mathrm{~L}^{-1} \mathrm{H}_{2} \mathrm{SO}_{4}$ (Table 1).

The above section summarizes the calibration curves, which were calculated from $\mathrm{CV}$ for the respective $\mathrm{Na}_{2} \mathrm{SO}_{4}$, $\mathrm{H}_{2} \mathrm{SO}_{4}, \mathrm{NaNO}_{3}$ and $\mathrm{HNO}_{3}$ solutions with both electrode types. Differences in the current densities were found between 0.100 and $0.002 \mathrm{~mol} \mathrm{~L}^{-1} \mathrm{NaNO}_{3}$ supporting electrolyte.

\section{Preconcentration and limit of detection (LOD)}

The anodic stripping voltammetry was applied to determine the lowest detectable As(III) concentration with the $6.47 \mathrm{~mm}^{2}$ silver wire electrode in $0.003 \mathrm{~mol} \mathrm{~L}^{-1} \mathrm{Na}_{2} \mathrm{SO}_{4}$ solution and $0.01 \mathrm{mmol} \mathrm{L}^{-1} \mathrm{As}(\mathrm{III})$ at $\mathrm{pH}$ 9.0. A study of time and voltage deposition was performed to optimize the conditions. Negative reduction voltages of $-0.4,-0.6$ and up to $-0.8 \mathrm{~V}$ with longer times of $300,900,1000,1500$ and $2000 \mathrm{~s}$ were assayed (see Table 2). The $-0.6 \mathrm{~V}$ and $2000 \mathrm{~s}$ were the selected parameters for the best LOD. The limit of detection was determined by measuring eleven samples at the lowest concentration $\left(3.3 \mathrm{nmol} \mathrm{L}^{-1}\left(250 \mathrm{ng} \mathrm{L}^{-1}\right)\right)$ and calculating $3 \sigma / m(\sigma=$ standard deviation of eleven determinations (in nmol L-1) and $m=$ slope of the calibration curve). ${ }^{9}$ The selected value of $-0.6 \mathrm{~V}$ was the same as the selected one by Compton et al. ${ }^{11}$ (data not shown). The found limit of detection was less than the reported LOD by Compton et al. ${ }^{11}$ by one order of magnitude because of the large accumulation time for arsenic and low scan rate, which decreased the background noise in the determination

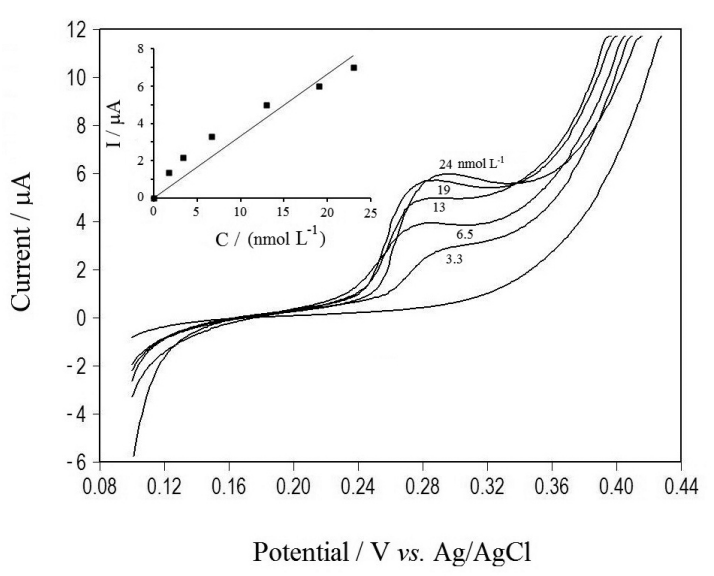

Figure 4. Anodic stripping voltammetry $\left(\mathrm{E}_{\mathrm{acc}}=-0.6 \mathrm{~V}, \mathrm{t}_{\mathrm{acc}}=2000 \mathrm{~s}\right)$ of $\operatorname{SWE}\left(6.47 \mathrm{~mm}^{2}\right)$ in $0.0033 \mathrm{~mol} \mathrm{~L}^{-1} \mathrm{Na}_{2} \mathrm{SO}_{4}$ and scan rate of $10 \mathrm{mV} \mathrm{s}^{-1}$.

by ASV (see Figure 4). The mechanism in accordance with ASV indicated that As(III) was reduced on the silver electrode according to:

$\operatorname{As}(\mathrm{III})+3 \mathrm{e}^{-} \rightarrow \operatorname{As}(0)$

Figure 4 presents the calibration curve in the range of 3.33-33.2 nmol L-1 and shows a slope (sensitivity) of $0.4 \mu \mathrm{A} \mathrm{nmol} \mathrm{L} \mathrm{L}^{-1}$. Eleven determinations at $1.4 \mu \mathrm{g} \mathrm{L} \mathrm{L}^{-1}$ $\left(18.68 \mathrm{nmol} \mathrm{L}^{-1}\right)$ for the reproducibility gave a standard deviation of $0.22 \mu \mathrm{A}$, corresponding to $3 \% \mathrm{RSD}$ (relative standard deviation). LOD of $90 \mathrm{ng} \mathrm{L}^{-1}\left(1.2 \mathrm{nmol} \mathrm{L}^{-1}\right)$ was calculated as three times the standard deviation over the calibration curve slope. This value was lower than those ones that were reported using a Ag electrode $\left(0.63 \mu \mathrm{mol} \mathrm{L}^{-1}\right)$ in $\mathrm{HNO}_{3}$ solution at $-0.6 \mathrm{~V}$ deposition potential at times of $120 \mathrm{s.}{ }^{11}$ This LOD was much lower than those ones obtained with a Pt electrode $\left(7.5 \mathrm{mg} \mathrm{L}^{-1}\right)\left(0.1 \mathrm{mmol} \mathrm{L}^{-1}\right){ }^{3}$ a hanging mercury drop electrode $\left(0.6 \mu \mathrm{g} \mathrm{L}^{-1}\right)\left(8 \mathrm{nmol} \mathrm{L}^{-1}\right),{ }^{5}$ a Pt electrode in flow injection analysis $\left(5 \mu \mathrm{g} \mathrm{L}^{-1}\right)\left(66.7 \mathrm{nmol} \mathrm{L}^{-1}\right)^{6}$ and an Au electrode $\left(0.15 \mu \mathrm{g} \mathrm{L}^{-1}\right)\left(2 \mathrm{nmol} \mathrm{L}^{-1}\right)$. This LOD was higher than that one found for the glassy carbon electrode modified with gold nanoparticles $\left(15 \mathrm{ng} \mathrm{L}^{-1}\right)\left(0.2 \mathrm{nmol} \mathrm{L}^{-1}\right){ }^{4}$

Table 2. Anodic stripping voltammetry (ASV) in $0.0033 \mathrm{~mol} \mathrm{~L}^{-1} \mathrm{Na}_{2} \mathrm{SO}_{4}$ with $\mathrm{SWE}\left(6.47 \mathrm{~mm}^{2}\right)$

\begin{tabular}{cccccc}
\hline Volume $\mathrm{As}(\mathrm{III}) / \mu \mathrm{L}$ & $\mathrm{C}_{\mathrm{As}(\mathrm{III})} /\left(\mathrm{mmol} \mathrm{L}^{-1}\right)$ & Deposition potential / & Deposition time / s & Peak current / $\mu \mathrm{A}$ & Anodic potential / V \\
\hline 5 & 1.00 & -0.4 & 900 & 1.500 & 0.300 \\
1 & 1.00 & -0.4 & 1500 & 3.500 & 0.280 \\
1 & 1.00 & -0.4 & 2000 & 2.648 & 0.310 \\
1 & 1.00 & -0.6 & 2000 & 6.330 & 0.286 \\
10 & 0.01 & -0.6 & 2000 & 4.990 & 0.272 \\
10 & 0.01 & -0.8 & 2000 & 3.440 & 0.325 \\
10 & 0.01 & -0.6 & 2000 & 7.219 & 0.272 \\
5 & 0.01 & -0.6 & 2000 & 3.523 & 0.270 \\
\hline
\end{tabular}


however, most likely due to the gold nanoparticles behaving like an electrode nanoarray. Considering the low limit that was found, the regression equation could be used to determine unknown samples at concentrations below the required limit by WHO for drinking or tap water. Simple linear voltammetry with SWE $\left(6.47 \mathrm{~mm}^{2}\right)$ at $10 \mathrm{mV} \mathrm{s}^{-1}$ determined a linear range of $1.33-13.33 \mu \mathrm{mol} \mathrm{L}^{-1}$ for As(III) when using $0.005 \mathrm{~mol} \mathrm{~L}^{-1} \mathrm{Na}_{2} \mathrm{SO}_{4}$ as supporting electrolyte (see Figure 5).

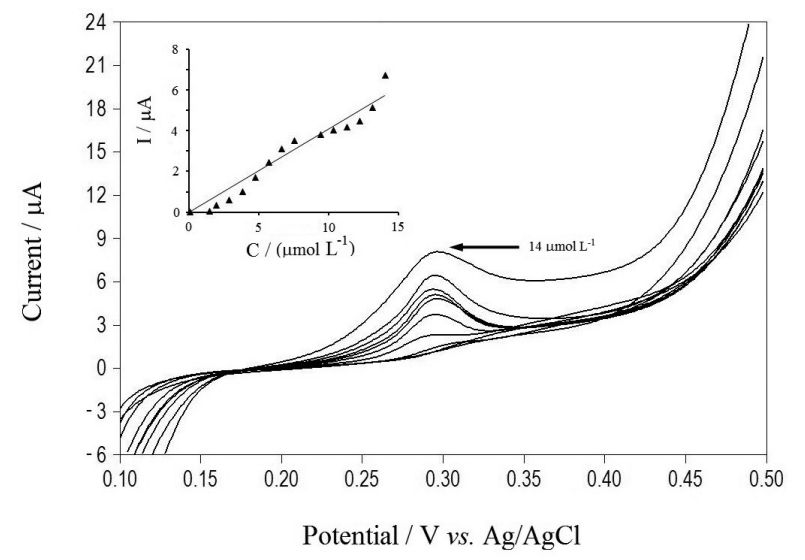

Figure 5. Linear voltammetry with SWE $\left(6.47 \mathrm{~mm}^{2}\right)$ in $0.005 \mathrm{~mol} \mathrm{~L}^{-1}$ $\mathrm{Na}_{2} \mathrm{SO}_{4}$.

\section{Effect of enhancement for solution alkalinity}

Because the supporting electrolytes in the above cases were unbuffered inorganic salts, the $\mathrm{pH}$ of the solutions varied between 7.0 and 9.0 when the added analyte was As(III) at $\mathrm{pH}$ 9.0. The arsenite detection was also performed in strongly alkaline conditions using the standard As(III) solutions at $\mathrm{pH} 13.0$ to investigate the $\mathrm{pH}$ effect. Figure 6 shows $\mathrm{CV}$ on SWE $\left(6.47 \mathrm{~mm}^{2}\right)$ in $0.1 \mathrm{~mol} \mathrm{~L}^{-1} \mathrm{Na}_{2} \mathrm{SO}_{4}$ solution at a scan rate of $20 \mathrm{mV} \mathrm{s}^{-1}$ and Figure 7 shows $\mathrm{CV}$ at $50 \mathrm{mV} \mathrm{s}^{-1}$. When comparing Figure 7 with CV of SWE $\left(6.47 \mathrm{~mm}^{2}\right)$ and As(III) at pH 9.0 in a $0.1 \mathrm{~mol} \mathrm{~L}^{-1} \mathrm{Na}_{2} \mathrm{SO}_{4}$ at a scan rate of $50 \mathrm{mV} \mathrm{s}^{-1}$, the As(III) oxidation potential decreased to $0.29 \mathrm{~V}$ with a better resolution of maximum definition and a higher current density. The process progressively becomes more irreversible, and at a high voltage scan rate, the slope of the calibration curve (inset Figure 7) was greater than the reported one in Table 1 at lower $\mathrm{pH}$. This phenomenon is the basis of $\mathrm{As}(\mathrm{III})$ tritations ${ }^{18}$ because $\mathrm{E}^{\mathrm{o}}$, for $\mathrm{As}(\mathrm{V}) / \mathrm{As}(\mathrm{III})$ varies with $\mathrm{E}^{\mathrm{o}}-0.059 \times \mathrm{pH}$. ( $\mathrm{E}^{\mathrm{o}}=$ secondary potential).

The decrease in the scan rate to $20 \mathrm{mV} \mathrm{s}^{-1}$ affected the resolution, and two oxidation waves were found for the most concentrated arsenic solutions. When the solution was at $\mathrm{pH} 11.0$, a shoulder appeared at $0.36-0.39 \mathrm{~V}$. The process occurring on the silver electrodes in alkaline solutions was previously reported, ${ }^{17,18}$ and the simplest mechanism that

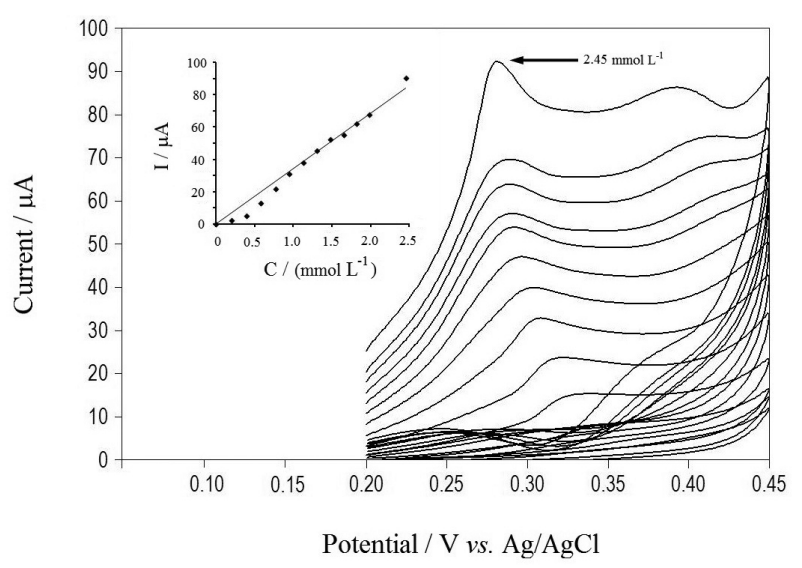

Figure 6. Cyclic voltammograms of SWE $\left(6.47 \mathrm{~mm}^{2}\right)$ in $0.1 \mathrm{~mol} \mathrm{~L}^{-1}$ $\mathrm{Na}_{2} \mathrm{SO}_{4}$ with $\mathrm{As}(\mathrm{III})$ at $\mathrm{pH} 13.0$ and scan rate of $20 \mathrm{mV} \mathrm{s}^{-1}$.

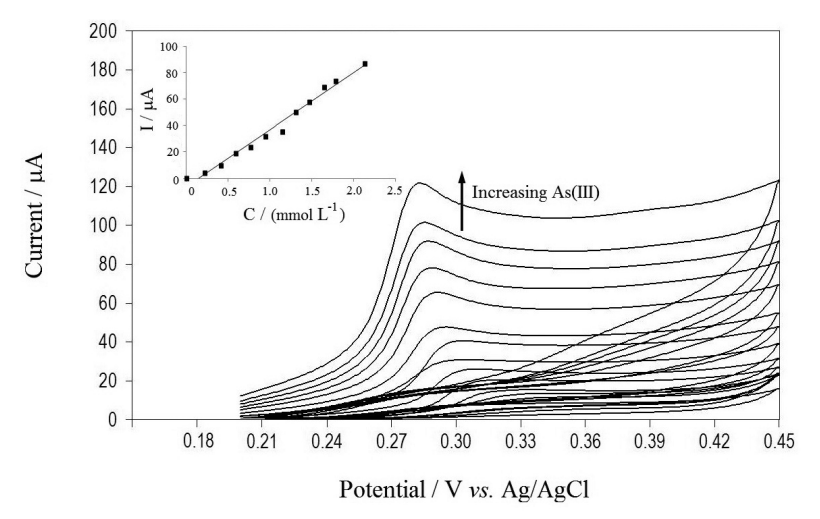

Figure 7. Cyclic voltammograms of SWE $\left(6.47 \mathrm{~mm}^{2}\right)$ in $0.1 \mathrm{~mol} \mathrm{~L}^{-1}$ $\mathrm{Na}_{2} \mathrm{SO}_{4}$ with $\mathrm{As}$ (III) at $\mathrm{pH} 13.0$ and scan rate of $50 \mathrm{mV} \mathrm{s}^{-1}$.

was estimated for a silver electrode in this media would involve a single hydroxyl. Furthermore, the silver electrodes in $1 \mathrm{~mol} \mathrm{~L}^{-1} \mathrm{NaOH}$ showed an anodic current peak near $360 \mathrm{mV}$, which could be ascribed to the electroformation of a multilayer of $\mathrm{Ag}_{2} \mathrm{O} .{ }^{19}$ This process has been previously reported to occur via nucleation and growth according to:

$2 \mathrm{Ag}+2 \mathrm{OH}^{-} \rightarrow \mathrm{Ag}_{2} \mathrm{O}+\mathrm{H}_{2} \mathrm{O}+2 \mathrm{e}^{-}$

The high $\mathrm{OH}^{-}$concentration would be a factor in determining the peak resolution of the voltamperogramm for arsenite detection, considering the reports on the effect of alkaline concentration on silver electrodes. ${ }^{19}$ The authors revealed that the rates of both hydrogen and oxygen evolutions were enhanced with increased $\mathrm{NaOH}$ concentration. Additionally, the involved charge in the electroformation of the oxide layer increased with increasing alkali concentration. Furthermore, the anodic and cathodic peak current densities increased with increasing $\mathrm{NaOH}$ concentration and shifted to slightly more negative values. The effects that were caused by the increasing $\mathrm{NaOH}$ concentration could be interpreted on the 
basis of the enhanced solubility of silver oxides at a more alkaline $\mathrm{pH} .{ }^{20}$ Moreover, the $\mathrm{Ag}_{2} \mathrm{O}$ layer that was generated on the silver electrode surface by the anodic sweep could serve as an intermediate in the arsenic anodic oxidation:

$3 \mathrm{Ag}(\mathrm{I})+\mathrm{As}(0) \rightarrow 3 \mathrm{Ag}(0)+\mathrm{As}(\mathrm{III})$

\section{Synthetic mixtures}

The effect of various ions which are usual components of natural water on arsenite detection (as well as the possible interferences in the electrode response) were evaluated by CV. The standard As(III) solution was prepared at $\mathrm{pH}$ 9.0. The interferences occurring at the same oxidation potential of As(III) would increase the peak current of the arsenic signal, minimizing its resolution. This phenomenon was attributed to the oxidation wave of arsenic and the occurrence of interference at the surface electrode, making anodic oxidation of arsenic more reversible. In this case, As(III) was detected using supporting electrolyte solutions with $\mathrm{Na}, \mathrm{Ca}$ and $\mathrm{Mg}$ salts in similar compositions to potable water. The effect of $\mathrm{HCO}_{3}{ }^{-}$was analyzed alone and together with other anions in water, including $\mathrm{SO}_{4}{ }^{2-}$ and $\mathrm{Cl}^{-}$. $\mathrm{SWE}\left(6.47 \mathrm{~mm}^{2}\right)$ was assayed in $0.002 \mathrm{~mol} \mathrm{~L}^{-1} \mathrm{NaCl}$, corresponding to $50 \mathrm{mg} \mathrm{L}^{-1}$ $\mathrm{Na}^{+}\left(2 \mathrm{mmol} \mathrm{L}^{-1}\right)$ and being the typical $\mathrm{Na}^{+}$content in tap water. The CV curves of As(III) at pH 10.0 and scan rate of $20 \mathrm{mV} \mathrm{s}^{-1}$ contained a wide maximum at $0.36 \mathrm{~V}$, with peak current increasing with As(III) content. A simple CV did not show the double peak at low salt concentration used. At this potential, the calibration curve had a $\mathrm{r}^{2}$ of 0.996 and a slope of $31.46 \mu \mathrm{A} \mathrm{mmol}^{-1} \mathrm{~L}$, very similar to the reported results for $0.1 \mathrm{~mol} \mathrm{~L}^{-1} \mathrm{NaNO}_{3}$ and $\mathrm{Na}_{2} \mathrm{SO}_{4}$.

In comparison with chloride anions, low bicarbonate anion concentrations had a more pronounced effect on the As(III) resolution at $\mathrm{pH} 9.0$ with a silver wire electrode $\left(6.47 \mathrm{~mm}^{2}\right)$. The $\mathrm{pH}$ range was 7.0-9.0. Solutions were prepared in milli-Q water with 0.7 and $1.0 \mathrm{mmol} \mathrm{L}^{-1}$ of $\mathrm{NaHCO}_{3}$, analyzed at $20 \mathrm{mV} \mathrm{s}^{-1}$ and presented double voltage peaks $(0.33$ and $0.4 \mathrm{~V})$ for the highest As(III) concentration $\left(1.13 \mathrm{mmol} \mathrm{L}^{-1}\right)$. It was likely that the $\mathrm{HCO}_{3}{ }^{-} / \mathrm{CO}_{3}{ }^{2-}$ equilibrium had an effect. The electrochemical behavior of polycrystalline silver electrodes in a highly concentrated $\mathrm{Na}_{2} \mathrm{CO}_{3}$ solution $\left(0.5-1.5 \mathrm{~mol} \mathrm{~L}^{-1}\right)$ was previously reported. ${ }^{21}$ It was found that the most probable electrooxidation reactions for $\mathrm{Ag}$ in aqueous $\mathrm{Na}_{2} \mathrm{CO}_{3}$ solution could be ascribed to the successive establishment of $\mathrm{Ag} / \mathrm{Ag}_{2} \mathrm{O}(344 \mathrm{mV})$ and $\mathrm{Ag} / \mathrm{Ag}_{2} \mathrm{CO}_{3}(477 \mathrm{mV})$ systems on the electrode surface. In our case, the peak potentials slightly shifted and the resolution of the current peak maximum decreased with increasing carbonate and arsenic concentrations. This behavior might be explained in terms of interferent effects between the anodic oxidation with the increasing solubility of $\mathrm{Ag}_{2} \mathrm{O}$ and $\mathrm{Ag}_{2} \mathrm{CO}_{3}$ at basic $\mathrm{pH}$.

In our work, it was observed the effect of hard water on the As(III) detection with SWE by adding basic salts of $\mathrm{Ca}$ and $\mathrm{Mg}$. Aqueous solutions of $\mathrm{Ca}^{2+}$ and $\mathrm{Mg}^{2+}$ salts were used as supporting electrolytes in compositions which were similar and in excess of tap water. For example, the SWE $\left(6.47 \mathrm{~mm}^{2}\right)$ response in a $\mathrm{CaCl}_{2}$ solution of $7.92 \mathrm{mg} \mathrm{L}^{-1} \mathrm{Ca}^{2+}\left(0.2 \mathrm{mmol} \mathrm{L}^{-1}\right)$ showed an irreversible enhancement of the current in the $\mathrm{pH}$ range of 7.0-11.0 for As(III) with broadened peaks, but was linear in the range of 0.093-1.33 mmol L-1 As(III). Similar results were obtained over magnesium sulfate at $1.2 \mathrm{mg} \mathrm{L}^{-1} \mathrm{Mg}^{2+}\left(0.05 \mathrm{mmol} \mathrm{L}^{-1}\right)$. A solution with $6.9 \mathrm{mg} \mathrm{L}^{-1} \mathrm{Ca}^{2+}\left(0.17 \mathrm{mmol} \mathrm{L}^{-1}\right)$ and $2.27 \mathrm{mg} \mathrm{L}^{-1} \mathrm{Mg}^{2+}\left(0.10 \mathrm{mmol} \mathrm{L}^{-1}\right)$ showed $\mathrm{I}=39.09 \mathrm{C}_{\text {AsIII }}$ $\left(\mu \mathrm{Ammol}^{-1} \mathrm{~L}\right)$ and a linear factor of 0.952 . Alkaline divalent cation salts likely produced greater fouling of the surface of the electrode, decreasing the measurement resolution.

\section{Tap or drinking water}

The SWE electrodes were used for analytical assays of tap water. A mixture of supporting electrolyte $\left(0.2 \mathrm{~mol} \mathrm{~L}^{-1}\right.$ $\left.\mathrm{Na}_{2} \mathrm{SO}_{4}\right)$ and tap water was prepared to contain $0.1 \mathrm{~mol} \mathrm{~L}^{-1}$ $\mathrm{Na}_{2} \mathrm{SO}_{4}$. The cyclic voltammograms of $\operatorname{SWE}\left(6.47 \mathrm{~mm}^{2}\right)$ in tap water samples at a scan rate of $20 \mathrm{mV} \mathrm{s}^{-1}$ were performed at different $\mathrm{As}$ (III) concentrations and monitored between $200 \mathrm{mg} \mathrm{L}^{-1}\left(2.67 \mathrm{mmol} \mathrm{L}^{-1}\right)$ and $25 \mu \mathrm{g} \mathrm{L}^{-1}\left(0.3 \mu \mathrm{mol} \mathrm{L}^{-1}\right)$ As(III). The standard As(III) solution in both cases was adjusted to $\mathrm{pH}$ 13.0.

The stripping mode with a $600 \mathrm{~s}$ of deposition time and potential of $-0.6 \mathrm{~V}$ was applied for the lowest $\mathrm{As}(\mathrm{III})$ concentration. Figure 8 shows the linear sweep voltammetry and the calibration curve between

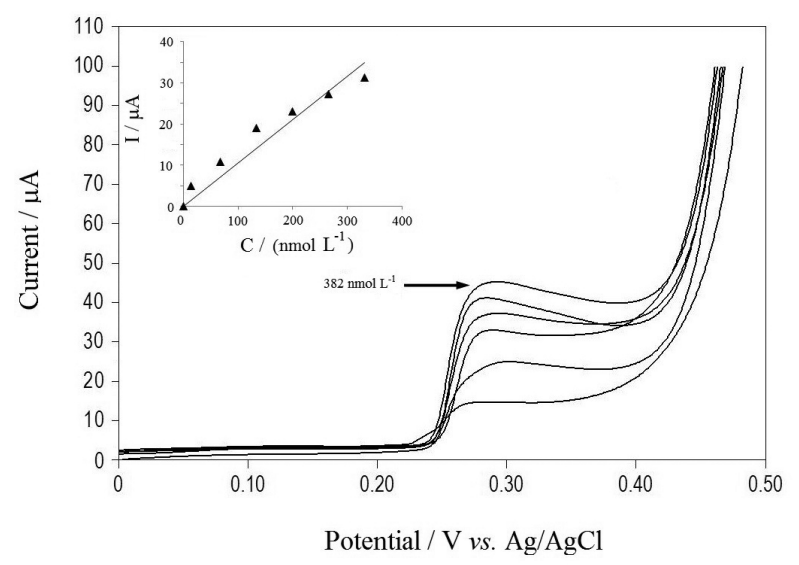

Figure 8. Linear sweep voltammograms of SWE $\left(6.47 \mathrm{~mm}^{2}\right)$ in a drinking water sample with $0.1 \mathrm{~mol} \mathrm{~L}^{-1} \mathrm{Na}_{2} \mathrm{SO}_{4}$ between 13 and $380 \mathrm{nmol} \mathrm{L}^{-1} \mathrm{As}$ (III) at $\mathrm{pH} 13.0$ and scan rate of $20 \mathrm{mV} \mathrm{s}^{-1}$. 
1-28.5 $\mu \mathrm{g} \mathrm{L}^{-1}$ (13.34-380 $\left.\mathrm{nmol} \mathrm{L}^{-1}\right)$ As(III), which included values deemed acceptable by the WHO for drinking water. The slope was $1.2 \mu \mathrm{A} \mu \mathrm{g}^{-1} \mathrm{~L}\left(0.1 \mu \mathrm{A} \mathrm{nmol}{ }^{-1} \mathrm{~L}\right)$ with a correlation coefficient of 0.960 . Figure 9 shows $\mathrm{CV}$ in which the highest $\mathrm{As}(\mathrm{III})$ concentration was added (200 $\mathrm{mg} \mathrm{L}^{-1}\left(2.67 \mathrm{mmol} \mathrm{L}^{-1}\right)$ ). The oxidation potential in these experiments was $0.3 \mathrm{~V}$. The calibration curve had a slope of $\mathrm{I} / \mathrm{C}_{\mathrm{As}(\mathrm{III})}=0.51 \mu \mathrm{A} \mathrm{mg}{ }^{-1} \mathrm{~L}\left(38.37 \mu \mathrm{A} \mathrm{mmol}^{-1} \mathrm{~L}\right)$. This was coincident with measurements that were made in $0.1 \mathrm{~mol} \mathrm{~L}^{-1} \mathrm{Na}_{2} \mathrm{SO}_{4}$ under similar conditions.

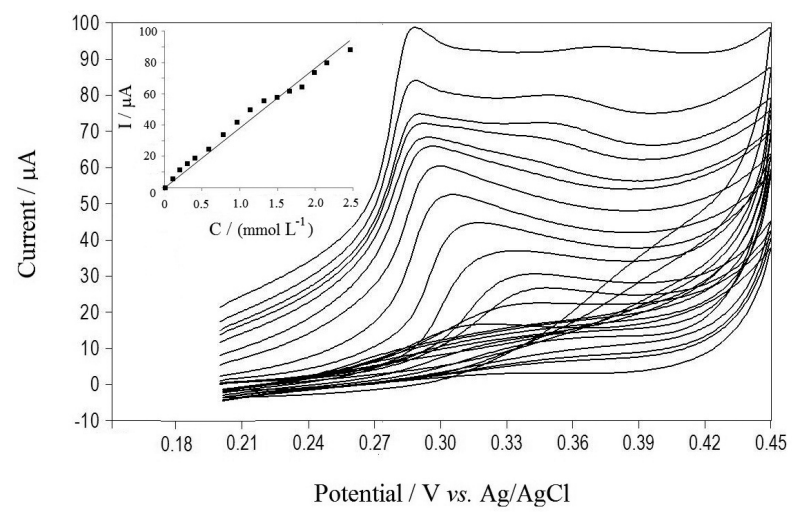

Figure 9. Cyclic voltammograms of $\operatorname{SWE}\left(6.47 \mathrm{~mm}^{2}\right)$ in a drinking water sample up to $2.67 \mathrm{mmol} \mathrm{L}^{-1} \mathrm{As}(\mathrm{III})$ and scan rate of $20 \mathrm{mV} \mathrm{s}^{-1}$.

The importance of this experiment is its possible use for monitoring water because As(III) could be detected at the $\mathrm{pH}$ of natural and seawater samples. Additionally, the results indicated that the silver electrode could be used to detect both the highest and the lowest assayed As(III) concentrations as a mixture with $\mathrm{As}(\mathrm{V})$.

\section{Conclusions}

To determine As(III) with SWE or SDE, inorganic solutions, such as $0.1 \mathrm{~mol} \mathrm{~L}^{-1} \mathrm{Na}_{2} \mathrm{SO}_{4}, \mathrm{NaNO}_{3}$ and $\mathrm{H}_{2} \mathrm{SO}_{4}$, may be used as the supporting electrolyte. The oxidation potential in this case was low, between 0.25 and $0.3 \mathrm{~V}$. The variation in the supporting electrolyte concentration did not significantly influence the detection resolution or the sensitivity. The wide linear range for different class of electrodes suggested a good possibility that the regression equation in each case could be used to determine unknown concentrations. The lowest LOD (90 $\left.\mathrm{ng} \mathrm{L}^{-1}\left(1.2 \mathrm{nmol} \mathrm{L}^{-1}\right)\right)$ indicated that SWEs could be used to detect trace quantities of arsenic in both basic and neutral media. Arsenic in tap water with $0.1 \mathrm{~mol} \mathrm{~L}^{-1} \mathrm{Na}_{2} \mathrm{SO}_{4}$ could be monitored across a wide concentration range (from $1.8 \mu \mathrm{g} \mathrm{L}^{-1}\left(24 \mathrm{nmol} \mathrm{L}^{-1}\right.$ ) to $\left.200 \mathrm{mg} \mathrm{L}^{-1}\left(2.67 \mathrm{mmol} \mathrm{L}^{-1}\right)\right)$.

Many ions (such as $\mathrm{Ca}^{2+}, \mathrm{Mg}^{2+}, \mathrm{Na}^{+}, \mathrm{SO}_{4}{ }^{2-}, \mathrm{HCO}_{3}{ }^{-}$and $\mathrm{Cl}^{-}$) are components of the natural water and could interfere with the electrode response even at the lowest analyzed concentrations. As such, a doubling effect of the voltage peak with bicarbonate was found.

The importance of these experiments lies in the demonstrated detection of $\mathrm{As}(\mathrm{III})$ at the typical $\mathrm{pH}$ of both natural and seawater samples, being convenient for monitoring purposes. The developed method showed linearity intervals higher than those ones that were previously reported with platinum and gold electrodes. Furthermore, it increased the sensitivity when applied to strongly alkaline conditions, and complex sample preparations were not necessary. Additionally, the results suggested that the silver electrode could be used to detect both high and low As(III) concentrations in a mixture with $\mathrm{As}(\mathrm{V})$.

\section{Acknowledgements}

The authors thank CIPA, PIA (Anillo ACT 130), and FONDECYT (Grant No. 1110079 and No. 11070056) for financial support.

\section{References}

1. Luong, J.; Majid, E.; Male, K.; Open Anal. Chem. J. 2007, 1,7 .

2. Brusciotti, F.; Duby, P.; Electrochim. Acta 2007, 52, 6644.

3. Cabelka, T. D.; Austin, D. S; Johnson, D. C.; J. Electrochem. Soc. 1984, 131, 1595.

4. Dai, X.; Nekrassova, O.; Hyde, M. E.; Compton, R. G.; Anal. Chem. 2004, 76, 5924

5. Barra,C. M.; Santos, M. M. C.; Electroanalysis 2001, 13, 1098

6. Lolic, A.; Nikolic, S.; Mutic, J.; Anal. Sci. 2008, 24, 877.

7. Kopanica, M.; Novotný, L.; Anal. Chim. Acta 1998, 368, 211.

8. Sun, Y. C.; Mierzwa, J.; Yang, M.-H.; Talanta 1997, 441, 379.

9. Dai, X.; Compton, R. G.; Analyst 2006, 131, 516.

10. Salaün, P.; Planer-Friedrich, B.; van den Berg, C. M. G.; Anal. Chim. Acta 2007, 585, 312.

11. Simm, A. O.; Banks, C. E.;Compton, R. G.; Electroanalysis 2005, 17, 1727.

12. Gorokhovskii, V. M.; J. Anal. Chem. 2003, 58, 3, 198.

13. Zaky, A. M.; Assaf, F. H.; Rehim, S. S. A.; Mohamed, B. M.; Appl. Surface Sci. 2004, 221, 349.

14. Hossain, M. M.; Islam, M. M.; Ferdousi, S.; Okajima, T.; Ohsakab, T.; Electroanalysis 2008, 20, 2435.

15. Fukushima, M.; Yanagi, H.; Hayashi, S.; Suganuma, N.; Taniguchi, Y.; Thin Solid Films 2003, 39, 438.

16. Shakkthivel, P.; Singh, P.; Int. J. Electrochem. Sci. 2007, $2,311$.

17. Thedford, P.; Dirkse , P.; Dale, B.; De Vries; D. B.; J. Phys. Chem. 1959, 63,107.

18. Burriel, F.; Conde, F.; Arribas, S.; Hernández, J.; Química Analítica Cualitativa; Editorial Paraninfo: Madrid, 1994. 
19. Rehim, S. S. A.; Hassan, H. H.; Ibrahim, M. A. M.; Amin, M. A.; Monatshefte für Chemie 1998, 129, 1103.

20. Druskovich, D. M.; Ritchie, I. M.; Singh, P.; Guang, Z. H.; Electrochim. Acta 1989, 34, 409.
21. Magdy, A. M.; Hamdy, H. I.; Sayed, S. H.; Rehim, A.; Mohamed, A.; J. Solid State Electrochem. 1999, 3, 380.

Submitted: March 5, 2011

Published online: November 10, 2011 